\title{
Genotoxic Effects of Karamenderes River (Canakkale/Turkey) Water Samples on Vicia faba L. Plant.
}

\author{
Meric Can Bayrak \\ Canakkale Onsekiz Mart University, \\ School of Graduate Studies, Subdivision of Biology, 17020, Canakkale, Turkey \\ E-mail: mericcanbayrak@gmail.com \\ Cuneyt Aki \\ Canakkale Onsekiz Mart University, Faculty of Science and Arts, \\ Department of Biology, Subdivision of Molecular Biology, 17020, Canakkale, Turkey \\ E-mail: cuneytaki@comu.edu.tr
}

\begin{abstract}
In this research the effects of Karamenderes River's water samples which collected from six different locations have been used for determining the genotoxic potential by the meaning of mitotic index analysis in Vicia faba $L$. In this research root tip test were used for mitotic index measuring. For comparing the effects of six different locations of Karamenderes River's water samples. Water samples have been applied on four weeks old V. faba plantlets. After 24 and 48 hours exposure time root tip test were realized. All experiments were carried out under controlled conditions in the plant growth chamber. According to our research results, it seems that water samples which collected from six different locations have been effected mitotic index differently. When we compare with control group, decreasing in mitotic index in $V$. faba have been shown especially in station five and six after 48 hours exposure time. After 24 hours of application decreasing has been observed as $43,99 \%$ and 50,30\% respectively when compared with the control group. After 48 hours of application decreasing has been observed as $47,11 \%$ and $51,07 \%$ respectively when compared with the control group. According to our research results, it was found that mitosis is affected at different levels in V. faba plantlets depending on the water quality and application time in the six stations of Karamenderes River.
\end{abstract}

Keywords: Vicia faba, Karamenderes River, Mitotic index.

DOI: $10.7176 / J S T R / 7-04-04$

\section{Introduction}

Water pollution is the general name given to pollution seen in areas that contain water such as lakes, rivers, oceans, seas and underground waters. Contaminated water that deteriorates as a result of water pollution, adversely affects human and animal health, and it also destroys the ecosystem balance by making life difficult because it destroys living spaces. In addition water, which is the basic requirement of plants, threatens growth when polluted.

Rapid population growth is one of the main factors contributing to water pollution. Consequently the pollution caused by chemicals emitted by agricultural activities to the environment and these pollutants directly or indirectly cause soil pollution. As a result of this problem, determining what soil pollutants are in the water content and the effects they cause is of great importance for the regions where agricultural activities are carried out. As a matter of fact, most of the water use in our country belongs to the agriculture sector. Pollution from agricultural pesticides and fertilizers alone causes the quality of water to deteriorate. Therefore, it can be concluded that agriculture is the main determinant of the quantity and quality of water available for other purposes.

In one of the research, it was conducted to evaluate the genotoxicity of heavy metals $(\mathrm{Cr}, \mathrm{Fe}, \mathrm{Ni}, \mathrm{Cd}$ and $\mathrm{Pb}$ ) within the GGV campus soils. Flowers were taken from Tradescantia pallida plants growing in this soil and micronucleus found in tetrates in pollen mother cells (Meravi et al., 2013)

30 | P a g e

www.iiste.org 
Another research has been conducted to evaluate the acute genotoxic effect of thermo-power plant waste water. Micronucleus test (MN), mitotic index and cell aberrations were observed on the root tips of Tradescantia. It was observed that the abnormal cell number in the root tips of Tradescantia plant. Micronucleus (MN) frequency in the cells increased significantly after the treatment (Elezaj et al., 2011).

The genotoxicity of sulfur dioxide hydrates in the roots of Allium sativum and Vicia faba plants was investigated. Various concentrations of a mixture of sodium sulfite and sodium bisulfite were used in this study. The $V$. faba anaphase aberration test was expressed by micronuclei test methods in both $V$. faba and A. sativum species. The numbers of micronucleus and chromosomal aberrations in both plant species were compared with the control groups and were found to be higher than the control group. Pycnotic cells have emerged in A. sativum root meristems. The increase in the doses of chemicals caused an increase in the number of cells with micronucleus, chromosomal changes, nuclei changes and delays in cell division (Meng and Yi, 2003).

The effects of different concentrations of lead $(0-20 \mu \mathrm{M})$ on stem cells of the $V$. faba species were analyzed. DNA breaks induced by lead were analyzed by comet test and chromosome aberrations by micronucleus test. In their data, it was stated that the induction of DNA fragmentation depending on the dose and the stimulation of micronuklues formation showed the genotoxic character of this metal. They evaluated the direct relationship of lead with DNA and did not reconcile the DNA breaks with the direct effect of lead on DNA. To investigate the relationship between lead genotoxicity and oxidative stress, they exposed $V$. faba to lead in the presence and absence of antioxidant vitamin E and NADPH oxidases. In the light of their studies, they analyzed the relationship between lead-induced chromosome aberrations, reactive oxygen species and DNA breaks (Pourrout et al., 2011).

In another research on the effect of wastewater, the cytogenetic effects of heavy metal and cyanide contaminated river water on A. cepa were investigated in the mining area in Southwest Bulgaria. This research was carried out in Panagjurishte region of Southwest Bulgaria, by using micronucleus and anaphase analysis, calculating mitotic and phase indices. Allium cepa was used as in vivo test material. The data obtained showed a reduction in cell proliferation and normal mitosis-micronucleus, anaphase and telophase bridges and fragments, delayed chromosomes and a C-mitotic effect. Cytogenetic analyzes have been performed to prove that biological imaging of water contaminated with heavy metals and cyanide is effective and appropriate (Ivanova et al., 2005).

The amount of lead in wastewater used in agricultural irrigation in Gaziantep, the extent of the pollution reached by the $V$. faba grown in that region was measured. As a result of the examination, it was determined that the amount of lead measured in the plants and the soil and irrigation water where the plants were grown showed a significant increase at the level of $\mathrm{P}<0.05$ compared to the control area. And also; It has been determined that the amount of lead in these plants is mostly accumulated in the root (Kafadar, 2010).

Allium root tip test has been used to analyze water quality. A. cepa bulbs were used to determine potential genotoxic effects on water samples taken from Civil brook. Tests were performed for germination percentage, root length, seed weight, mitotic index (MI), chromosomal abnormalities, micronucleus $(\mathrm{MN})$ changes. Vanadium $(\mathrm{V})$, chromium $(\mathrm{Cr})$, cobalt $(\mathrm{Co})$, nickel $(\mathrm{Ni})$, copper $(\mathrm{Cu})$, zinc $(\mathrm{Zn})$, arsenic $(\mathrm{As})$, cadmium $(\mathrm{Cd})$, titanium $(\mathrm{TI})$, lead $(\mathrm{Pb})$ in stream water ) and heavy metals such as iron $(\mathrm{Fe})$ were determined. The results showed that pollution in stream water should be considered as a danger and a warning to the health of the environment and living organisms (MahmutDoğan et al., 2018)

\section{Materials and Methods}

\subsection{Plant Material}

The certified Vicia faba L. seeds were purchased from Ceylan Agricultural Company (Turkey).

\subsection{Plant Growing}

The plantlets were grown until four weeks old in pots under controlled conditions in a 1:3 perlite:soil mixture. Four weeks old plantletswere irrigated every two days with water samples which taken from six different stations of Karamenderes River. Control group was irrigated with distilled water. All experimental series were carried out as triplicate (Figure 1). 

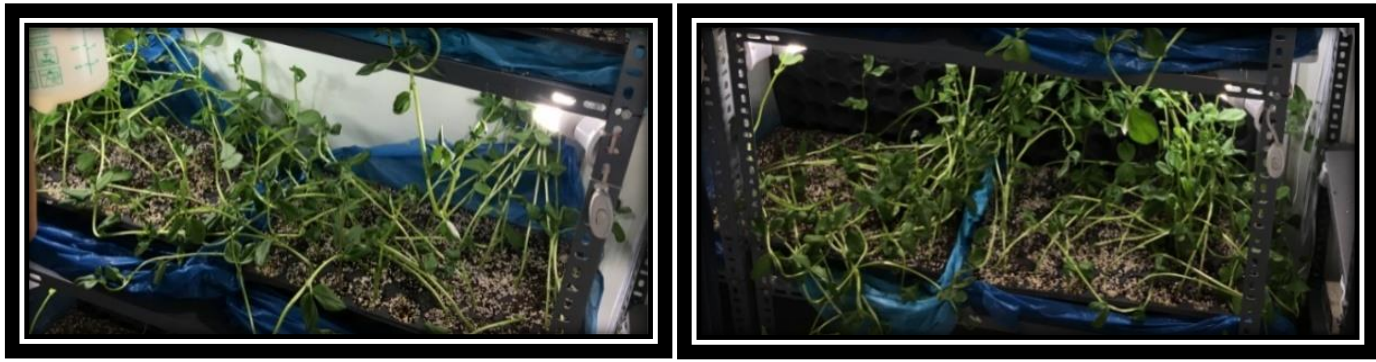

Figure 1- 4 weeks old V. faba samples

\subsection{Taking Water Samples from Karamenderes River and Analysis of Water}

Karamenderes River water samples were taken into sterilized one liter glass bottles from six different (Bayramiç, Ahmetçeli, Sarımsakçı, Pınarbaşı, Kalafat and Kumkale) stations (Figure 2, Figure 3). Some of the water samples were sent to ÇOBILTUM (Çanakkale Onsekiz Mart University Science and Technology Application and Research Center) for (ICP-OES elemental analysis, alkalinity, chemical oxygen demand, organic matter, salinity) analysis. The other part of the water samples has been sent to MAKU BILTEKMER (Burdur Mehmet Akif Ersoy University Science and Technology Application and Research Center) for GS/MS pesticide analysis.

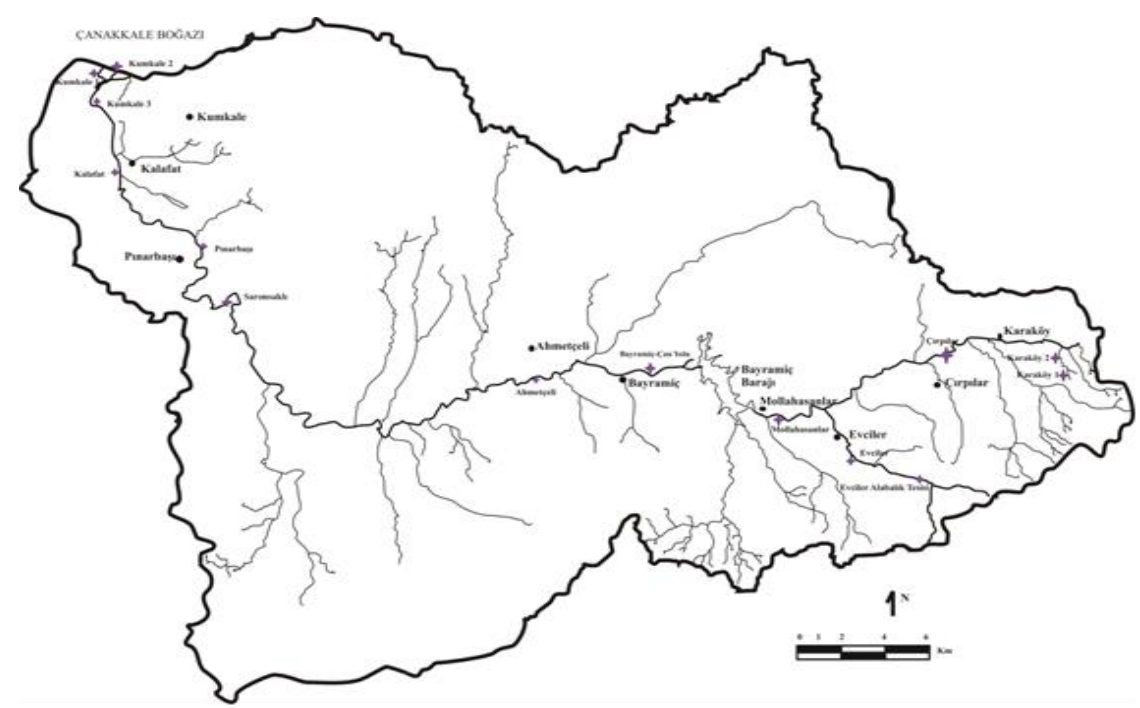

Figure 2- Map of Karamenderes River and six water samples locations. 


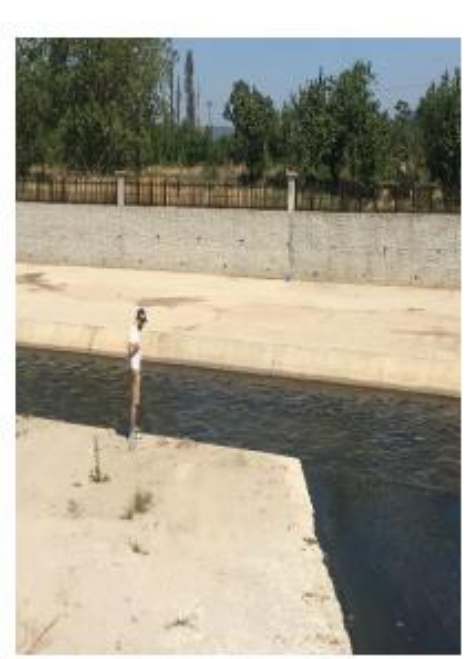

(A)

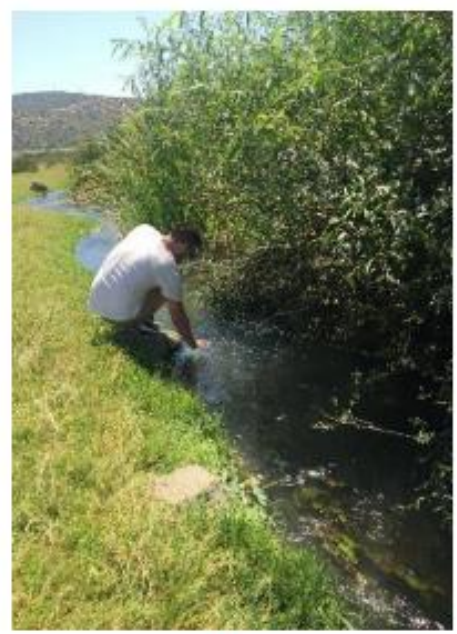

(D)

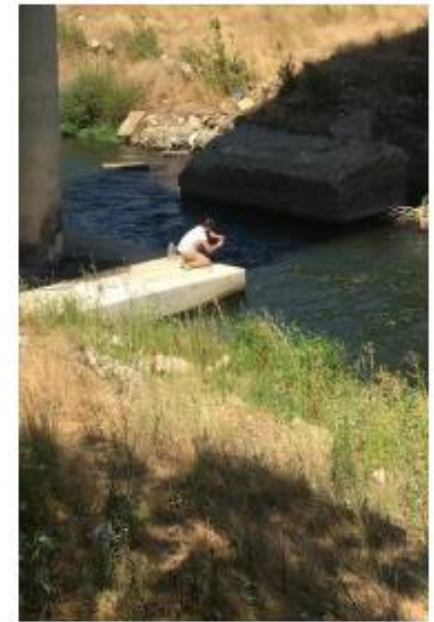

(B)

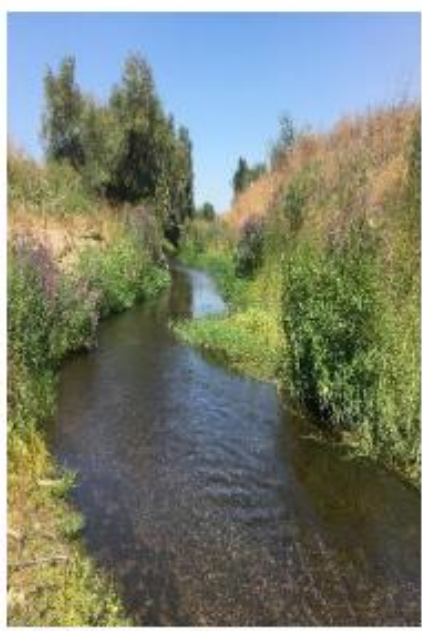

(E)

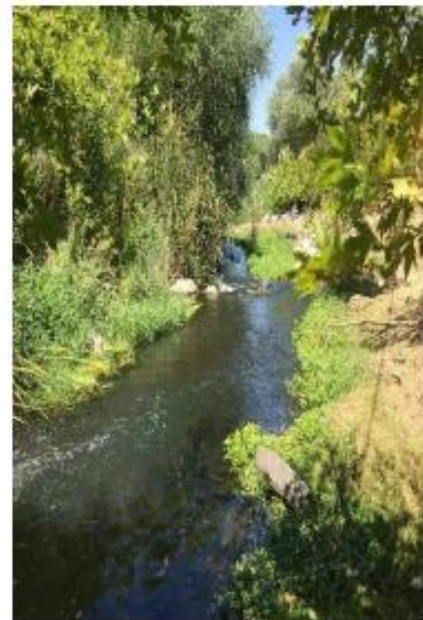

(C)

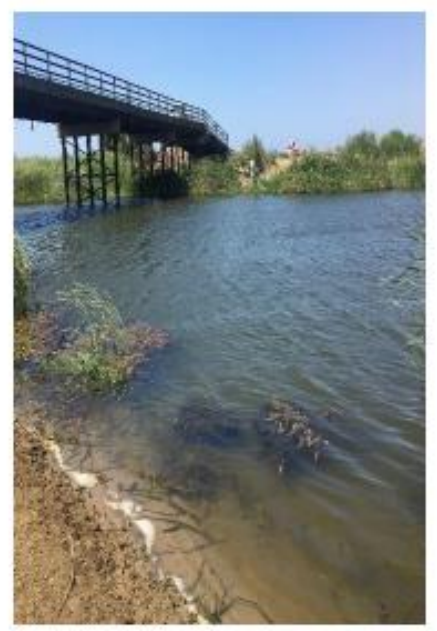

(F)

A-Bayramiç station, B-Ahmetçeli station, C-Sarımsaklı station, D-Pınarbaşı station

E- Kalafat station, F- Kumkale station

Figure 3- Taking water samples from Karamenderes River

\subsection{Application of Karamenderes River Water Samples to Vicia faba Plantlets}

The root tips of four weeks old $V$. faba plantlets have been irrigated two times with the water samples which taken from the six different stations. Control group was irrigated with distilled water. 24 and 48 hours after application $V$. faba root tips were cut in the early morning hours and washed with distilled water three times. These root tips were taken into the farmer fixative ( 3 parts ethanol: 1 part glacial acetic acid) and then placed in the refrigerator in dark glass bottles at $+4{ }^{\circ} \mathrm{C}$ until microscopy.

\subsection{Mitotic Analysis}

\subsubsection{Root Tip Test and Mitotic Index Calculation}

By cytological observation of mitotic stages in meristematic cells, mitotic activity (index) can be calculated. Mitotic activity is the ratio of dividing cells to non-dividing meristematic cells. It is generally used in chromosome count studies and toxicological studies. Thus, if there is application with a chemical substance, it gives information about how the substance has an effect on the splitting rate. The mitotic index is calculated in $\%$ by the following formula 
$M I=\left(\frac{\text { Number of Dividing Cells }}{\text { Total Number of Observed Cells }}\right) \times 100$

\subsubsection{Prepearing Vicia faba Root Tips for Microscopy Process}

Standard root tip test method has been used for hydrolyze and chromosome staining. Hydrolysis process has been realized in $1 \mathrm{~N} \mathrm{HCl}$ at $60^{\circ} \mathrm{C}$ water bath for 10 minutes and then they were rinsed with distilled water. After staining with aceto-carmine, root tips kept in carmine in falcon tubes for 2 days in the refrigerator. Then, approximately 2-3 mm of root tips were cut from the darker colored ends of the root tips, acetocarmine was dropped on it again and a coverglass was covered. Blocking paper was covered on the coverslip and the root tip was slightly crushed over it, allowing the cells to be distributed in a single layer. Microscopic observations have been made with the Olympus CX-31 research microscope, individual cells were counted for each group showing abnormalities with cells undergoing mitosis. In order to investigate the mitotic index and the ratio of anomalies among the preparations belonging to the control group and six applications group, cells with anomalies were counted.

\section{Results and Discussion}

In our research, water samples were taken from six different stations of the Karamenderes (Skemendros) River, which originates from the Ida Mountains (Kazdağı) and flows into the Kumkale Delta approximately $100 \mathrm{~km}$ further, and consists of many branches.

\subsection{Mitotic Index Results}

Water samples taken from Karamenderes River were applied on four weeks old $V$. faba plantlets. 24 and 48 hours after water applications root tip test have been realized. In the root tip samples of V. faba, normal mitosis and different mitotic abnormalities were observed (Figure 4).

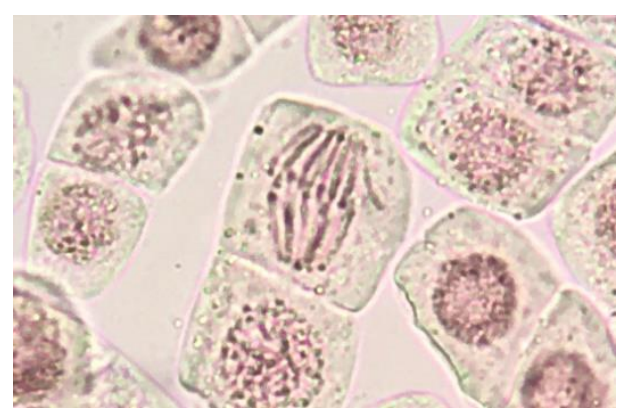

(A)

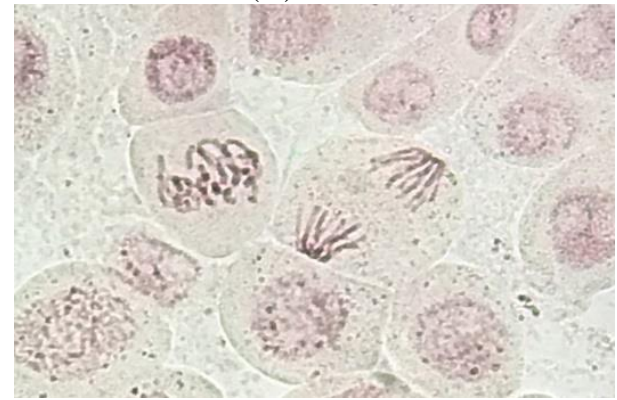

(C)

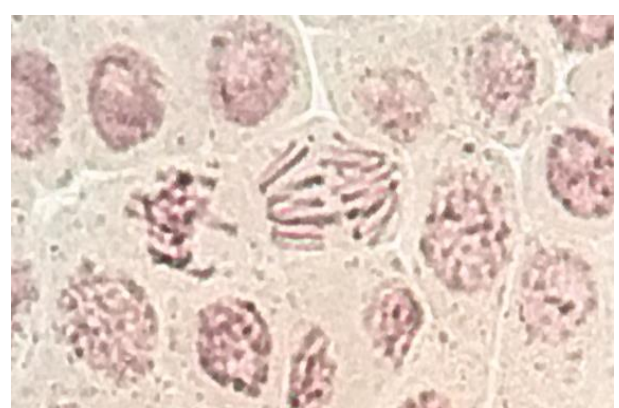

(B)

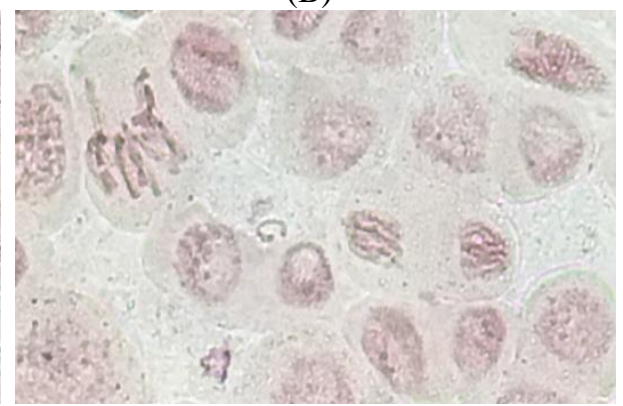

(D)

a. Anaphase lagging b. Failure to separate chromatids in the anaphase c. Pole shift, d. Abnormal metaphase

Figure 4- The negative effects of water taken from different stations on mitosis.

As a result of our research, it was understood that the mitotic index decreased in application groups when we compare with the control group. Applications of six different water samples with different exposure times affected mitosis and mitotic index at different levels.

Our research results are shown in figures (Table 1, Table 2, Figure 5). It was observed that the

34 | P a g e

www.iiste.org 
mitotic index values decreased in parallel with the results of the analyzed water samples. The decrease in mitotic index shows that Karamenderes river water is genotoxic and inhibits cell division. Especially, it was observed that water samples taken from Kumkale (6th station) affected the plants negatively the most (Table 1).

Among the chromosomal abnormalities observed, deformation at the prophase stage; pole shift in metaphase stage, irregular chromosome distribution, chromosome breaks; Irregular chromosome distribution in the anaphase phase, residual chromosomes, pole shift, bridge formation, chromosome non-separation; In the telophase phase, pole shift, loose chromosome, chromosome fractures, transverse division were detected. Chromosome splices have also been seen.

Table 1- Mitotic index results in $V$. faba root tip cells 24 hours after applications

\begin{tabular}{|c|c|c|c|c|c|c|c|}
\hline Groups & Prophase & Metaphase & Anaphase & Telophase & $\begin{array}{c}\text { Number of Dividing } \\
\text { Cells }\end{array}$ & $\begin{array}{c}\text { Total of } \\
\text { Dividing Cells }\end{array}$ & $\begin{array}{c}\text { Mitotic } \\
\text { Index }\end{array}$ \\
\hline Control & 44 & 21 & 29 & 13 & 107 & 1249 & 8,566 \\
\hline 1 & 39 & 16 & 21 & 8 & 85 & 1108 \\
\hline 2 & 33 & 29 & 16 & 15 & 93 & 1216 & 7,767 \\
\hline 3 & 28 & 12 & 16 & 9 & 65 & 1193 & 5,448 \\
\hline 4 & 25 & 14 & 11 & 9 & 58 & 1096 & 5,291 \\
\hline 5 & 19 & 9 & 11 & 12 & 51 & 1063 & 4,797 \\
\hline 6 & 18 & 14 & 8 & 7 & 47 & 1104 & 4,257 \\
\hline
\end{tabular}

Table 2- Mitotic index results in $V$. faba root tip cells 48 hours after applications

\begin{tabular}{|c|c|c|c|c|c|c|c|}
\hline Groups & Prophase & Metaphase & Anaphase & Telophase & $\begin{array}{c}\text { Number of Dividing } \\
\text { Cells }\end{array}$ & $\begin{array}{c}\text { Total of } \\
\text { Dividing Cells }\end{array}$ & $\begin{array}{c}\text { Mitotic } \\
\text { Index }\end{array}$ \\
\hline Control & 38 & 28 & 21 & 14 & 101 & 1197 & 8,437 \\
\hline 1 & 37 & 27 & 17 & 10 & 91 & 1248 & 7,291 \\
\hline 2 & 31 & 25 & 16 & 11 & 83 & 1164 & 7,130 \\
\hline 3 & 29 & 9 & 21 & 5 & 64 & 1212 & 5,280 \\
\hline 4 & 19 & 11 & 18 & 6 & 54 & 1047 & 5,157 \\
\hline 5 & 22 & 19 & 13 & 11 & 54 & 1210 & 4,462 \\
\hline 6 & 20 & 14 & 7 & 8 & 49 & 1187 & 4,128 \\
\hline
\end{tabular}

Number of the Dividing Cells 10000

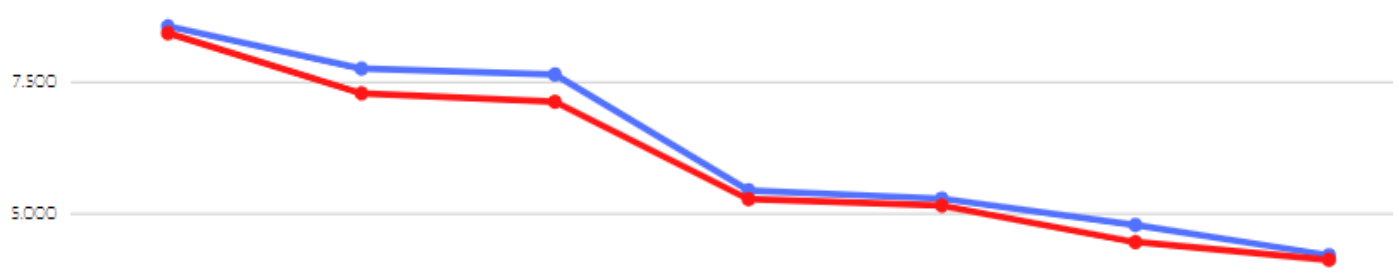

2.500

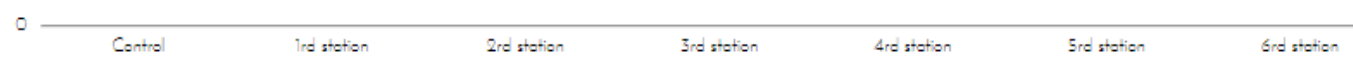

Figure 5- Comparing exposure times in mitotic index (Blue: 24 hours after, Red: 48 hours after)

\subsection{Water Analysis Results}

Some of the water sampleswere sent to ÇOBILTUM (Çanakkale Onsekiz Mart University Science and

35 | P a g e

www.iiste.org 
Technology Application and Research Center) for (ICP-OES elemental analysis, alkalinity, chemical oxygen demand, organic matter, salinity) analysis. Water analysis results have been given in Table 3 and Table 4

Table3- Water analysis of Karamenderes River.

\begin{tabular}{|c|c|c|c|c|c|c|c|}
\hline Parameter & & 1 & 2 & 3 & 4 & 5 & 6 \\
\hline $\mathrm{P}$ & $\mathrm{mg} / \mathrm{L}$ & 0,1 & 0,082 & 0,25 & 0,138 & 0,102 & 0,411 \\
\hline $\mathrm{Ba}$ & $\mu \mathrm{g} / \mathrm{L}$ & 30,85 & 31,69 & 56,52 & 80,82 & 102,5 & 109 \\
\hline $\mathrm{Br}$ & $\mu \mathrm{g} / \mathrm{L}$ & 34,57 & 19,63 & 32,91 & 37,31 & 54,67 & 316,4 \\
\hline $\mathrm{Mg}$ & $\mathrm{mg} / \mathrm{L}$ & 14,56 & 10,28 & 14,01 & 17,19 & 23,26 & 61,61 \\
\hline $\mathrm{Ca}$ & $\mathrm{mg} / \mathrm{L}$ & 60,99 & 40,3 & 52,16 & 61,21 & 69,51 & 83,06 \\
\hline $\mathrm{Na}$ & $\mathrm{mg} / \mathrm{L}$ & 17,1 & 13,98 & 21,3 & 26,55 & 36,08 & 413,8 \\
\hline $\mathrm{K}$ & $\mathrm{mg} / \mathrm{L}$ & 2,996 & 1,73 & 3,257 & 3,339 & 2,698 & 17,27 \\
\hline Salinity & $\mathrm{g} / \mathrm{L}$ & 0,2 & 0,2 & 0,2 & 0,2 & 0,3 & 1,1 \\
\hline Alkalinity (CO3) & $\begin{array}{c}\mathrm{mg} / \mathrm{L} \\
\mathrm{CaCO}_{3}\end{array}$ & 12 & 5 & 0 & 3 & 8 & 16 \\
\hline Alkalinity (HCO3) & $\begin{array}{c}\mathrm{mg} / \mathrm{L} \\
\mathrm{CaCO}_{3}\end{array}$ & 175 & 114 & 154 & 174 & 221 & 405 \\
\hline $\begin{array}{l}\text { Chemical Oxygen } \\
\text { Demand }\end{array}$ & $\mathrm{mg} / \mathrm{L}$ & $<16$ & $<16$ & 19,29 & $<16$ & $<16$ & 24,31 \\
\hline Organic Matter in Water & $\operatorname{mg~02/1}$ & 3,2 & 3,2 & 3 & 3 & 2,8 & 5 \\
\hline
\end{tabular}

Table 4- Pesticide Analysis in Karamenderes River.

\begin{tabular}{|c|c|c|c|c|c|c|}
\hline Sample & $\begin{array}{c}\text { alfha-BHC } \\
(\mathbf{p p m})\end{array}$ & $\begin{array}{c}\text { Gamma- } \\
\text { BHC (ppm) }\end{array}$ & $\begin{array}{c}\text { Delta-BHC } \\
(\mathbf{p p m})\end{array}$ & $\begin{array}{c}\text { Heptachlor } \\
(\mathbf{p p m})\end{array}$ & $\begin{array}{c}\text { 4DDD } \\
(\mathbf{p p m})\end{array}$ & $\begin{array}{c}\text { Eldrin } \\
(\mathbf{p p m})\end{array}$ \\
\hline 1 & 0,0049 & 0,0025 & 0,0014 & 0,0009 & 0,0028 & 0,0050 \\
\hline 2 & 0,0070 & 0,0012 & 0,0014 & 0,0024 & 0,0006 & 0,0045 \\
\hline 3 & 0,0046 & 0,0024 & 0,0009 & 0,0007 & - & 0,0005 \\
\hline 4 & 0,0038 & 0,0021 & 0,0008 & 0,0007 & - & 0,0003 \\
\hline 5 & 0,0512 & - & 0,0857 & - & - & - \\
\hline 6 & 0,0802 & - & 0,1599 & - & - & - \\
\hline
\end{tabular}

\subsection{Discussion}

Düsman et al. (2013) This study was conducted to monitor the cytotoxic potential of the Quatorze river, located in the Brazilian town of Francisco Beltrão, Paraná, using the A.cepa L. root meristematic. The results showed that the effluent from points 2,3 and 4 was not cytotoxic because A. cepa cell division was unchanged. The 1st chain, on the other hand, has a larger mitotic index than the negative control, which indicates that water contains a high mitogenic capacity. However, according to the mitotic index values of the river water, the pollution was reduced along the route from point 1 to point 4 , probably by a self-purification mechanism. The results show that monitoring from point 1 can be processed for 24 hours. MI information for A. серa L. roots has increased. In addition, it is likely that pollutants are at source near this point, but self-purification is possible along the river.

In another research Firbas and Amon (2013) With this study, it is aimed to show the effectiveness of the cleaning facility of social wastewater in wetlands. Tests The degree of genotoxicity is demonstrated by observing plant A.cepametaphasic chromosome abnormalities induced by genotoxic substances in contaminated water with the Allium cepa L. metaphase test.

In another research conducted by Oliveira et al. (2012), it was found that the Sinosriver was exposed to pollutants due to the population increase in the Vale dos Sinos region in recent years. Therefore, it has become important to utilize this river water in these highly industrialized regions. This study aims to analyze some of the physicochemical parameters of the industrial and urban garbage of the cities of Novo Hamburgo (NH) and São Leopoldo (SL), as well as the toxic and genotoxic water effects of the 
Sinosriver. For this, water samples were taken in summer and autumn for A.cepa test and some physicochemical analysis. These water samples show that +6 valent chromium (CR) found in physicochemical analysis may be responsible for inducing toxicity and genotoxicity in A. cepa,E. crassipes meristematic cells.

In another research the effects of Umurbey, Bakacak, Bayramiç and Atikhisar dams on mitosis and chromosomes in A. cepa plant were examined in regions exposed to effects such as agricultural activities and mineral exploration. In T. pallida species, it was evaluated by stamen hair analysis. According to the results of the research, it was determined that as a result of 72 hours treatment of $A$. сера root tips with water taken from different dams, there was a decrease in mitotic index values compared to the control group. In addition, the most common chromosome anomalies were found to be irregular chromosome distribution in the metaphase phase, and inactive chromosomes, pole shift and bridge formation in the anaphase and telophase phases. When compared to the control group 96 hours after the application of dam water to T. pallida stamen hair cells, it was determined that the number of pink mutation cells increased between 2.12 and 3.89 times compared to the control group. Based on these results, it was determined that the mutation levels in both plants differ depending on the dam locations. At the same time, it was determined that both genotoxicity tests used in the study gave parallel results with the same sensitivity (Doğan and Aki., 2016).

In a research conducted by the effects of Kocabaş River water's exposed to industrial and domestic wastes on mitosis and chromosomes in Allium cepa and Vicia faba plants were investigated. As a result, after 48 hours and 72 hours of application to Allium cepa and Vicia faba plants, various mitotic abnormalities were observed in parallel with the application time in addition to normal mitosis in the plants studied. Mitotic index values of Allium cepa species were 9.07 in the control group, while they were 8.50 in the 3rd station; In Vicia faba plant, it was 10.19 in the control group and 7.25 in the 4th station. The decrease in mitotic index shows that Kocabaş River's water is genotoxic and inhibits cell division (Vodina and Aki, 2017).

\section{Conclusion}

In our country, some of the wastewater is discharged into rivers or seas without treatment. These waters can cause various diseases in humans as a result of the consumption of such contaminated agricultural products by mixing with the resources used for irrigation of agricultural lands.

Considering environmental pollution as a whole, prevention of pollution appears to be the most rational solution instead of eliminating pollution. While the contribution of individual approaches and nongovernmental organizations to the solution of the environmental problem cannot be underestimated, the most important part here is undoubtedly the state policy. The state must first take all kinds of precautions in its own facilities, and show these measures as "exemplary".

Hacioğlu (2012) was used to evaluate our study, taking into account the table of water pollution parameters. According to these parameters, there is not so much danger and pollution for genotoxicity in Karamenderes River water.

\section{Acknowledgements}

This research is a part of Meriç Can BAYRAK's Master Thesis project which supported financially by Çanakkale Onsekiz Mart University Scientific Research Projects Coordination Unit by FYL-2019-3073 project code. We would like to thank to Assoc. Prof. Dr. Nurcihan HACIOĞLU DOĞRU for helping us with interpretation of water analysis.

\section{References}

Doğan, M, Yalçın, E, Acar, A, Çavuşoğlu, D, Şengül, Ü , Yapar, K, Çavuşoğlu, K. (2018). Investigation of Physiological, Cytogenetic and Anatomical ChangesInducedByHeavy Metal IonsFound In Water of CivilStream In AlliumcepaL. ( Amaryllidaceae) Gaziosmanpaşa Bilimsel Araştırma Dergisi , 7 (2) , 1-13

Doğan Levent S., Akı C. (2016). "Effects of Different Dam Waters on Allium cepa L. and Tradescantia pallida H. Plant Species", Annals of Biological Research, vol.7, pp.5-8. 
Düsman E.,Luzza M., Savegnago L., Lauxen D,. Vicentını V.E.P.,Tonıal I.B.,T1c1anePokrywieckiSauer T.P. (2013).Alliumcepa L. as a bioindicatorto measurecytotoxicity of surfacewater of theQuatorzeRiver, located in Francisco Beltrão, Paraná, Brazil. 10.1007/s10661-013-3493-8.

Elezaj I.R.,Mıllaku L.B., Imer1-Millaku R.H., Selımı Q.I., And Letaj K.R.. (2011). AcuteGenotoxicEffects of EffluentWater of Thermo-PowerPlant "Kosova" In TradescantiaPallida. Journal of Chemical Health Risks 1(1): 23-28,

Firbas P., And Amon T. (2013). AlliumChromosomeAberration Test for Evaluation Effect of CleaningMunicipalWaterwithConstructedWetland $(\mathrm{CW})$ in SvetiTomaž, Slovenia., J BioremedBiodeg 2013, 4:4.

Hacioğlu, N., and Dülger, B. (2010). Montlyvariation of somephysico-chemical and microbiologicalparameters in SaricaySteam (Canakkale, Turkey)",. Fresenius EnvironmentalBulletin, vol.19, 986-990.

Ivanova E., Staikova T. A., Velcheva I. (2005). Cytogenetic Testing of Heavy Metal and Cyanide Contaminated River Waters in a Mining Region of Southwest Bulgaria. Journal of Cell and Molecular Biology, 4: 99-106.

Kafadar F., Saygideğer S. (2010). Determination of Lead (Pb) content in some agricultural plants irrigated with industrial waste water around Gaziantep province. Ecology, 19 (75): 41-48.

Meravi N., Prajapati S.K. (2013). Effects of heavy metals/metalloids contamination of soils on micronucleus induction in Tradescantia pallida. Environmental Skeptics and Critics, 2 (2): 58-62.

Pourrout B., Jean S., Silvestre J., Pinellı E. (2011). LeadInduced DNA Damage in Vicia fabaRootCells: Potentialİnvolvement of OxidativeStress. MutationResearch, 726: 128.

Vodina R., Ak1 C. (2017). "GenotoxicEffects of Biga Kocabaş River'sWater on Alliumcepa L. and Vicia faba L. PlantSpecies", VIII. Uluslararası Ekoloji ve Çevre Sorunları Sempozyumu ÇANAKKALE, Türkiye, 4-7 Ekim, pp.54-154.

Yi H., Meng Z. (2003).Genotoxicity of Hydrated Sülfür Dioxide on Root Tips of Allium sativumand Vicia faba. Mutation Research, 537: 109-114. 